LINGUA, Vol. 16, No. 2, September 2019

p ISSN: 1979 9411; e ISSN: 2442 238X

Http://lingua.soloclcs.org; Email: presslingua@gmail.com

Center of Language and Cultural Studies, Surakarta, Indonesia

Suhirman, Lalu. 2019. Body Language and Its Meaning:

the Interpretation of Body Language in the Little Black Book Film.

Lingua (2019), 16(2): 175-194. Http://doi.org/10.30957/lingua.v16i2.266.

\title{
Body Language and Its Universal Meaning: the Interpretation of Body Language in the Little Black Book Film
}

\author{
LaluSuhirman \\ Universitas Cenderawasih Jayapura, Papua \\ E-mail: lalusuhermanmpd@gmail.Com
}

\begin{abstract}
This study aims to examine body language, namely facial expressions that appear in film scenes entitled 'Little Black Book'. Therefore, this study discusses two research questions: 1) what conventional meaning is expressed by the facial expressions of central figures in 'Little Black Book' film? 2) what are the forms and patterns of body language that carry important messages besides facial expressions in 'Little Black Book' film? This study uses a qualitative approach to analyze data. The data source of this research is the film "Little Black Book". The data of this study are certain scenes related to body language. Data is collected through observation, which is watching carefully and repeatedly, and cutting or copying images that show gesture or gesture of body language. The result found was facial expressions which specified at upper neck, namely: head, eyes, and mouth. while the other parts of body language were hands and other acts of body language.
\end{abstract}

Key-words: body language, facial expression, non-verbal language

\section{INTRODUCTION}

Since humans are born, we can see body language in their behavior, even though they have not been able to speak a simple example, if a baby cries, maybe he wants to say that he is thirsty or hungry, or maybe he feels pain, fear, worry, anger, and many other interpretations. Before humans can speak, he first interacts using his body language and always uses his body language to express his intentions and desires. He might move his hands, nod his head to express approval, or shake his head left and right to express rejection.

Body language is the unspoken or non-verbal mode of communication that we do in every single aspect of our interaction with another person. It is like a mirror that tells us what the other person thinks and feels in response to our words or actions. Body language involves gestures, mannerisms, and other bodily signs (Nierenberg \& Calero, 2010; Eggert, 2010). Eggert (2010) further asking about the frequency of using body language in daily communication, 'would you believe that in real life situations, $60 \%$ to $80 \%$ of the messages that we convey to other people are transmitted through body language and the actual verbal communication accounts for only $7 \%$ to $10 \%$ ? ' Our ability to use body language in a positive way and to read other people's minds through 
LINGUA, Vol. 16, No. 2, September 2019

p ISSN: 1979 9411; e ISSN: 2442 238X

Http://lingua.soloclcs.org; Email: presslingua@gmail.com

Center of Language and Cultural Studies, Surakarta, Indonesia

Suhirman, Lalu. 2019. Body Language and Its Meaning:

the Interpretation of Body Language in the Little Black Book Film.

Lingua (2019), 16(2): 175-194. Http://doi.org/10.30957/lingua.v16i2.266.

their body language separates the men from the boys (or women from girls), and can be a powerful tool to our overall personality development. Imagine creating a great impression for work, business, and love by being knowledgeable in this not-so-common yet powerful field of study. It is the unspoken tool to a successful life (Given, 2002; P.L.R., 2008; Niereberg \& Calero, 2012).

Most of the basic communication guestures are the same all over the world. When are people happy the smile, when they are sad or angry the frown or scowl. Nodding the head is almost universally used to indicate 'yes' or affirmation. It appears to be a form of head lowering and is probably an inborn gesture. As also used by deaf and blind people. Shaking the head form side to side indicate 'no' or negation is alsouniversal and may well be a gesture that is learned in infacy. When a baby has had enough milk, he turn his head from side to side reject his mother's breast. When the young child has had enough to eat, he shakes his head from side to side to stop his parent's attempt to spoon feed himan in this way he quickly learns to use the head shaking gesture to show disagreement or a negative attitude (Peas, 1984).

There are two common essential aspects of human communication: verbal and nonverbal. The verbal communication is concerned with the spoken language to convey messages. Whilst, the nonverbal communication is the process of communicating messages through the use of facial language, body movement, tone of voice, gestures, eye contact and so on. Thus, body language represents one of the most influential means of visual nonverbal behaviour including body movement, gesture, facial expression and so on (James, 2007; Eggert, 2010). Facial expressions imply a disclosure of different emotions and interpersonal behaviour that reveal certain characterisations of a person or a message. Therefore, facial expressions are an important channel of nonverbal communication. Thus, facial expressions are crucial for social communication, especially because they make it possible to express and perceive unspoken emotional and mental states (Ekman, 2005).

Thus, this study aims to examine body language, namely facial expressions that appear in film scenes entitled 'Little Black Book'. Therefore, this study discusses two research questions: 1) what conventional meaning is expressed by the facial expressions of central figures in 'Little Black Book' film? 2) what are the forms and patterns of body language that carry important messages besides facial expressions in 'Little Black Book' film?

The title of this film is "Little Black Book", it talks about a pretty girl whose family was broken home. Her parents were divorced. Brittany Murphy was casted as Stacy Holt. This Little Black Book is easy to capture the audiences' heart in this wickedly funny film about a really nice girl who's a disaster waiting to happen. Hired to work on a tabloid TV show, Stacy Holt's life gets turned upside down when she is persuaded to explore one of show's times, and snoops through her boy friend's Palm Handheld. But she forgot one thing: in the world of daytime TV, there's always shocking surprise in store. 
LINGUA, Vol. 16, No. 2, September 2019

p ISSN: 1979 9411; e ISSN: 2442 238X

Http://lingua.soloclcs.org; Email: presslingua@gmail.com

Center of Language and Cultural Studies, Surakarta, Indonesia

Suhirman, Lalu. 2019. Body Language and Its Meaning:

the Interpretation of Body Language in the Little Black Book Film.

Lingua (2019), 16(2): 175-194. Http://doi.org/10.30957/lingua.v16i2.266.

This film was released in 2004 as the best romantic comedy of the year. This film has been watched by young people all over the world. This film was reproduced in 2008 by Revolution Studio, and Dutamitra company in Indonesia.

\section{REVIEW OF LITERATURE}

\subsection{Body Language}

Albert (1971) defined body language as a form of non-verbal communication. Givens (2002:33) defined non-verbal communication as "the process of sending and receiving wordless messages by means of facial expressions, gaze, gestures, postures, and tones of voice". Crystal (2008) in line with Given's view that non-verbal communication is considered as non-linguistic features of communication including facial expression and gestures. The body language includes "the systematic use of facial expression andbody gesture to communicate meaning, especially as this relates to the use of language" (James, 2007).

Body language is a form of nonverbal communication. Humans send and interpret such signals sometimes unconsciously. It may provide clues as to the attitude or state of mind of a person. Body language is "the unspoken or non-verbal mode of communication that we use in every single aspect of our interaction with another person. It is like a mirror that tells us what the other person thinks and feels in response to our words or actions" (Edwards, 2008:12).Body language is an outward reflection of a person's emotional condition. Each gesture or movement can be a valuable key to an emotion a person may be feeling at the time. For example, a man who is self-conscious about gaining weight may tug at the fold of skin under his chin; the woman who is aware of extra pounds on her thighs may smooth her dress down; the person who is feeling fearful or defensive might fold their arms or cross their legs or both; and a man talking with a large-breasted woman may consciously avoid staring at her breasts while, at the same time, unconsciously use groping gestures with his hands (Allan \& Pease, 2004).

The shoulder shrug is also a good example of a universal gesture that is used to show or understand what you are talking about. it is multiple gestures that have three main parts, exposed palms, hunched shoulders, and raised brow. just as verbal language differs from culture to culture, so the non-verbal language also differs. Whereas on gesture may be common in a particular culture and have a clear interpretation, it may be meaningless in another culture or even have completely (Allan \& Pease, 2004).

\subsection{Facial Expression}

Facial expression is the most important area for non-verbal signalling and is believed to be the primary source of information next to human speech (Knapp, 1978:263). It is a multi-message system: (1) it can communicate information regarding (1) one's personality; (2) it expresses emotional states and interpersonal attitudes; and (3) it can provide interaction signals. According to Bowden (2010) 'reading faces' is very important as "faces can tell the whole story" (p.96). Therefore, body language namely facial expressions are the main ways for humans to communicate their emotions 
LINGUA, Vol. 16, No. 2, September 2019

p ISSN: 1979 9411; e ISSN: 2442 238X

Http://lingua.soloclcs.org; Email: presslingua@gmail.com

Center of Language and Cultural Studies, Surakarta, Indonesia

Suhirman, Lalu. 2019. Body Language and Its Meaning:

the Interpretation of Body Language in the Little Black Book Film.

Lingua (2019), 16(2): 175-194. Http://doi.org/10.30957/lingua.v16i2.266.

and intentions, which are the most complex messages communicated by human nonverbal behaviour (Pantic, et al., 2007).

A British research team led by Christoper Brannigan and David Humphries (cited by Nierenberg \& Calero, 2012:28-29), has separated and made a list of 135 different body languages, three of which are very common smiles, including simple smile, smile, and a big smile. Based on a simple smile analysis the teeth are not visible, generally seen when someone does not participate in the activities that are happening. He smiled to himself. In a smile, the upper incisors are visible and eye contact usually occurs between individuals. A big smile, generally when someone is having fun and is often associated with laughter, the upper and lower incisors are visible, and eye contact often occurs (Eggert, 2010).

There is a considerable history is associated with the link between emotions and facial and body language. Charles Darwin (as cited in Nierenberg \& Calero, 2012:27) was the first to describe in detail the specific facial and bodily expressions associated with emotions in animals and humans. The human face is the preeminent means of expressing and interpreting somebody's affective states based on the shown facial expressions. Darwin argued that all mammals show emotions reliably in their faces. Ekman (2005) stated that the human body configuration and movement also reveal and enhance emotions. For example, an angry face is more menacing when accompanied by a fist. Thus, any specific facial expression can be immediately associated with a specific emotion (De Gelder, 2006; James, 2007; Wiley \& Sons, 2007).

\section{METODOLOGY}

This study uses a qualitative approach to analyze data. The data source of this research is the film "Little Black Book". The data of this study are certain scenes related to body language. Data is collected through observation, which is watching carefully and repeatedly, and cutting or copying images that show gesture or gesture of body language. Data were analyzed using Discourse Analysis suggested by John Austin (1995). Before being analyzed, data is sorted and classified into themes or topics that are relevant to the research problem. Then, the researcher interpreted the data to answer the research problem. Triangulation methodology is used to re-examine the data and interpretations made by the researcher in accordance with other sources. The aim is to check the reliability of data collection and discovery. In addition, it is done to reduce the subjectivity of qualitative content analysis (Bogdan and Biklen, 1998).

\section{FINDINGS}

Facial expressions identified in this finding are the upper neck, namely: head, eyes, and mouth. while the other parts of body language are hands and other acts of body language. 


\subsection{Head}

\begin{tabular}{|c|c|c|c|}
\hline No. & The sign of body language & Possible meaning & Detailed Explanation \\
\hline 1. & Shaking head & disagreement & $\begin{array}{l}\text { Sideways shaking of the head } \\
\text { generally indicates } \\
\text { disagreement, but also signal } \\
\text { feelings of dibelief, frustretion } \\
\text { or exasperation. Obvious of } \\
\text { course but often ignored or } \\
\text { missed where movement is } \\
\text { small, especially in groups } \\
\text { seemingly reacting in silent } \\
\text { acceptance. }\end{array}$ \\
\hline & $\begin{array}{c}\text { Shakes her head left and } \\
\text { right }\end{array}$ & & \\
\hline 2. & $\begin{array}{l}\text { Nodding down and up } \\
\text { instead putting left hand on } \\
\text { the left cheek }\end{array}$ & agreement & $\begin{array}{l}\text { Head nodding can occur when } \\
\text { invited for response, or } \\
\text { voluntarily while listening. A } \\
\text { deft person is clear response for } \\
\text { nodding it means yes or agree. } \\
\text { Head nodding seems that } \\
\text { almost all ethnic groups and } \\
\text { cultures remark as an } \\
\text { agreement. We Indonesian } \\
\text { people also comonly nodding } \\
\text { head down and up to state } \\
\text { agreement. Nodding down for a } \\
\text { few seconds, or minutes can } \\
\text { mean praying or exressing sad. }\end{array}$ \\
\hline 3. & Raising head/titled head & $\begin{array}{l}\text { Interested in } \\
\text { someone or } \\
\text { something }\end{array}$ & $\begin{array}{l}\text { When someone raises his/her } \\
\text { head it indicates that he/she is } \\
\text { interested in to someone or } \\
\text { something }\end{array}$ \\
\hline 4. & Raising eyebrow & $\begin{array}{l}\text { Getting } \\
\text { recognition, } \\
\text { acknowledgement }\end{array}$ & $\begin{array}{l}\text { Quickly raising and lowering } \\
\text { the eyebrows is an eyebrow } \\
\text { flash. It is a common signal of } \\
\text { greeting and acknowledgement, } \\
\text { and is perhaps genitically } \\
\text { influence since it is prevalent. } \\
\text { Fear and suprise are also }\end{array}$ \\
\hline
\end{tabular}


LINGUA, Vol. 16, No. 2, September 2019

p ISSN: 1979 9411; e ISSN: 2442 238X

Http://lingua.soloclcs.org; Email: presslingua@.gmail.com

Suhirman, Lalu. 2019. Body Language and Its Meaning:

the Interpretation of Body Language in the Little Black Book Film.

Lingua (2019), 16(2): 175-194. Http://doi.org/10.30957/lingua.v16i2.266.

\begin{tabular}{|l|l|l|l|}
\hline & & $\begin{array}{l}\text { signalled by the eyebrow flash, } \\
\text { in which case the eyebrows } \\
\text { normally remain raised for } \\
\text { longer, until the initial shock } \\
\text { subsides. }\end{array}$ \\
\hline 5. & $\begin{array}{l}\text { Knit the eyebrow } \\
\text { (Barb) }\end{array}$ & $\begin{array}{l}\text { Confuse, } \\
\text { disagree, like to } \\
\text { the speaker }\end{array}$ & $\begin{array}{l}\text { When someone knits his/her } \\
\text { eyebrow, it indicates that he } \\
\text { /she is confuse to the speaker or } \\
\text { disagree to the speaker. }\end{array}$ \\
(Stacy and her friend) & & \\
\hline
\end{tabular}

4.2. Eyes

\begin{tabular}{|l|l|l|l|}
\hline No. & $\begin{array}{l}\text { The sign of Body } \\
\text { Language }\end{array}$ & $\begin{array}{l}\text { Possible } \\
\text { Meanining }\end{array}$ & Detailed Explanation \\
\hline 1. & Eyes widening & $\begin{array}{l}\text { Interest, appeal, } \\
\text { invitation }\end{array}$ & $\begin{array}{l}\text { Widening the eyes generally signals } \\
\text { interest in something or someone, } \\
\text { and often invites positive response. } \\
\text { Widened eyes with raised eyebrows } \\
\text { can otherwise be due to shock, but } \\
\text { aside from this, widening eyes } \\
\text { represents an opening and } \\
\text { welcoming expression. In women } \\
\text { especially widened eyes tend to } \\
\text { increase attractiveness, which is } \\
\text { believed by some body language } \\
\text { experts to relate to the eye/face } \\
\text { proportions of babies, and the } \\
\text { associated signals of attraction and } \\
\text { prompting urges to protect and offer } \\
\text { love and care, etc. }\end{array}$ \\
\hline
\end{tabular}


LINGUA, Vol. 16, No. 2, September 2019

p ISSN: 1979 9411; e ISSN: 2442 238X

Http://lingua.soloclcs.org; Email: presslingua@gmail.com

Center of Language and Cultural Studies, Surakarta, Indonesia

Suhirman, Lalu. 2019. Body Language and Its Meaning:

the Interpretation of Body Language in the Little Black Book Film.

Lingua (2019), 16(2): 175-194. Http://doi.org/10.30957/lingua.v16i2.266.

\begin{tabular}{|c|c|c|c|}
\hline 2. & $\begin{array}{l}\text { looking right } \\
\text { (generally) }\end{array}$ & $\begin{array}{l}\text { creating, } \\
\text { fabricating, } \\
\text { guessing, lying, } \\
\text { storytelling }\end{array}$ & $\begin{array}{l}\text { Creating here is basically making } \\
\text { things up and saying them. } \\
\text { Depending on context this can } \\
\text { indicate lying, but in other } \\
\text { circumstances, for example, } \\
\text { storytelling to a child, this would be } \\
\text { perfectly normal. Looking right and } \\
\text { down indicates accessing feelings, } \\
\text { which again can be a perfectly } \\
\text { genuine response or not, depending } \\
\text { on the context, and to an extent the } \\
\text { person. }\end{array}$ \\
\hline 3. & looking left (generally) & $\begin{array}{l}\text { recalling, } \\
\text { remembering, } \\
\text { retrieving 'facts' }\end{array}$ & $\begin{array}{l}\text { Recalling and and then stating } \\
\text { 'facts' from memory in appropriate } \\
\text { context often equates to telling the } \\
\text { truth. Whether the 'facts' } \\
\text { (memories) are correct is another } \\
\text { matter. Left downward looking } \\
\text { indicates silent self-conversation or } \\
\text { self-talk, typically in trying to arrive } \\
\text { at a view or decision. }\end{array}$ \\
\hline 4. & Joyce & $\begin{array}{l}\text { disbelief, upset, } \\
\text { or tiredness }\end{array}$ & $\begin{array}{l}\text { Rubbing eyes or one eye can } \\
\text { indicate disbelief, as if checking the } \\
\text { vision, or upset, in which the action } \\
\text { relates to crying, or tiredness, which } \\
\text { can be due boredom, not necessarily } \\
\text { a need for sleep. If the signal is } \\
\text { accompanied by a long pronounced } \\
\text { blink, this tends to support the } \\
\text { tiredness interpretation. }\end{array}$ \\
\hline 5. & 'flash')( & $\begin{array}{l}\text { greeting, } \\
\text { recognition, } \\
\text { acknowledgement }\end{array}$ & $\begin{array}{l}\text { Quickly raising and lowering the } \\
\text { eyebrows is called an 'eyebrow flash'. } \\
\text { It is a common signal of greeting and } \\
\text { acknowledgement, and is perhaps } \\
\text { genetically influenced since it is } \\
\text { prevalent in monkeys (body language } \\
\text { study does not sit entirely happily } \\
\text { alongside creationism). Fear and } \\
\text { surprise are also signalled by the } \\
\text { eyebrow flash, in which case the } \\
\text { eyebrows normally remain raised for } \\
\text { longer, until the initial shock subsides. }\end{array}$ \\
\hline
\end{tabular}




\begin{tabular}{|c|c|c|c|}
\hline 6. & $\begin{array}{l}\text { direct eye contact } \\
\text { (when listening) }\end{array}$ & $\begin{array}{l}\text { attentiveness, } \\
\text { interest, attraction }\end{array}$ & $\begin{array}{l}\text { Eyes which stay focused on the } \\
\text { speakers eyes, tend to indicate focused } \\
\text { interested attention too, which is } \\
\text { normally a sign of attraction to the } \\
\text { person and/or the subject. }\end{array}$ \\
\hline & Stacy \& Barb & & \\
\hline
\end{tabular}

\subsection{Mouth}

\begin{tabular}{|c|c|c|c|}
\hline & $\begin{array}{l}\text { The sign of Body } \\
\text { Language }\end{array}$ & $\begin{array}{l}\text { Possible } \\
\text { Meanining }\end{array}$ & Detailed Explanation \\
\hline 1. & The Smug Smile & $\begin{array}{l}\text { the self } \\
\text { satisfied, } \\
\text { arrogant, }\end{array}$ & $\begin{array}{l}\text { Lips - Usually pressed together and } \\
\text { only one side coming up. Can be done } \\
\text { with a lips slightly separated. The upper } \\
\text { lip may also rise a bit. } \\
\text { Usually a sign of self satisfaction, } \\
\text { arrogance and expression of superiority. } \\
\text { It can also be a sign of doubt and an } \\
\text { attempt to dismiss someone's opinion. } \\
\text { If the upper lip rises - it's probably a } \\
\text { sign of ridicule. } \\
\text { Interestingly, it can be used in flirting } \\
\text { as a sign of humor and playfulness - to } \\
\text { try and catch attention and interest from } \\
\text { the other side. }\end{array}$ \\
\hline & Barb and Stacy & $\begin{array}{l}\text { This smile is } \\
\text { quite similar to } \\
\text { the smug, only } \\
\text { with a slight } \\
\text { adjustment and } \\
\text { a different } \\
\text { meaning, } \\
\text { sarcasm, } \\
\text { embarrassment } \\
\text { or cynicism. }\end{array}$ & $\begin{array}{l}\text { Lips - One half of the lips creates a } \\
\text { smile, the other half expressing frown. } \\
\text { It's actually not that natural to make this } \\
\text { face expression, so it's quite rare in my } \\
\text { experience. } \\
\text { It sends a conflict message - is it a } \\
\text { smile or a frown? Usually it's a sign of } \\
\text { sarcasm, embarrassment or cynicism. } \\
\text { This smiling face can stir some } \\
\text { protective and attentive emotional } \\
\text { response in the eyes of the viewer - we } \\
\text { connect to the person with his half } \\
\text { smile, and feel empathy because of the } \\
\text { sad half }\end{array}$ \\
\hline
\end{tabular}


LINGUA, Vol. 16, No. 2, September 2019

p ISSN: 1979 9411; e ISSN: 2442 238X

Http://lingua.soloclcs.org; Email: presslingua@gmail.com

Center of Language and Cultural Studies, Surakarta, Indonesia

Suhirman, Lalu. 2019. Body Language and Its Meaning:

the Interpretation of Body Language in the Little Black Book Film.

Lingua (2019), 16(2): 175-194. Http://doi.org/10.30957/lingua.v16i2.266.

\begin{tabular}{|c|c|c|c|}
\hline 3. & $\begin{array}{l}\text { Open Mouth Smile } \\
\text { A BIG smile with an } \\
\text { open mouth }\end{array}$ & $\begin{array}{l}\text { positive } \\
\text { attention and } \\
\text { suggests } \\
\text { happiness }\end{array}$ & $\begin{array}{l}\text { Lips - A wide open smile with the } \\
\text { jaw drops down - it looks like a } \\
\text { frozen laughter. } \\
\text { It's a more trained smile really... } \\
\text { used to draw a lot of positive } \\
\text { attention and suggests happiness } \\
\text { mixed with playfulness. You can see } \\
\text { a lot of politicians and actors with } \\
\text { smiling faces like these for } \\
\text { photogenic photos }\end{array}$ \\
\hline 4 & pursing lips & $\begin{array}{l}\text { thoughtfulness, } \\
\text { or upset }\end{array}$ & $\begin{array}{l}\text { As if holding the words in the mouth } \\
\text { until they are ready to be released. } \\
\text { Can also indicate anxiousness or } \\
\text { impatience at not being able to } \\
\text { speak. Or quite differently can } \\
\text { indicate upset, as if suppressing } \\
\text { crying. }\end{array}$ \\
\hline 5. & tong & $\begin{array}{l}\text { disapproval, } \\
\text { rejection }\end{array}$ & $\begin{array}{l}\text { The tongue extends briefly and } \\
\text { slightly at the centre of the mouth as } \\
\text { if tasting something nasty. The } \\
\text { gesture may be extremely subtle. An } \\
\text { extreme version may be } \\
\text { accompanied by a wrinkling of the } \\
\text { nose, and a squint of the eyes. }\end{array}$ \\
\hline 6. & $\begin{array}{l}\text { hand clamped over } \\
\text { mouth }\end{array}$ & $\begin{array}{l}\text { suppression, } \\
\text { holding back, } \\
\text { shock }\end{array}$ & $\begin{array}{l}\text { Often an unconscious gesture of } \\
\text { self-regulation - stopping speech for } \\
\text { reasons of shock, embarrassment, or } \\
\text { for more tactical reasons. The } \\
\text { gesture is reminiscent of the 'speak } \\
\text { no evil' wise monkey. The action } \\
\text { can be observed very clearly in } \\
\text { young children when they witness } \\
\text { something 'unspeakably' naughty or } \\
\text { shocking. Extreme versions of the } \\
\text { same effect would involve both } \\
\text { hands. }\end{array}$ \\
\hline
\end{tabular}




\subsection{Hand}

\begin{tabular}{|c|c|c|c|}
\hline & $\begin{array}{l}\text { The sign of Body } \\
\text { Language }\end{array}$ & $\begin{array}{l}\text { Possible } \\
\text { Meanining }\end{array}$ & Detailed Explanation \\
\hline 1. & palm(s) up or open & $\begin{array}{l}\text { submissive, } \\
\text { truthful, honesty, } \\
\text { appealing }\end{array}$ & $\begin{array}{l}\text { Said to evolve from when open } \\
\text { upward palms showed no } \\
\text { weapon was held. A common } \\
\text { gesture with various meanings } \\
\text { around a main theme of } \\
\text { openness. Can also mean "I } \\
\text { don't have the answer," or an } \\
\text { appeal. In some situations this } \\
\text { can indicate confidence (such } \\
\text { as to enable openness), or } \\
\text { trust/trustworthiness. An easily } \\
\text { faked gesture to convey } \\
\text { innocence. Outward open } \\
\text { forearms or whole arms are } \\
\text { more extreme versions of the } \\
\text { signal. }\end{array}$ \\
\hline 2. & $\begin{array}{l}\text { finger pointing (at a } \\
\text { person) }\end{array}$ & $\begin{array}{l}\text { aggression, threat, } \\
\text { emphasis }\end{array}$ & $\begin{array}{l}\text { Pointing at a person is very } \\
\text { confrontational and dictatorial. } \\
\text { Commonly adults do this to } \\
\text { young people. Adult to adult it } \\
\text { is generally unacceptable and } \\
\text { tends to indicate a lack of } \\
\text { social awareness or self-control } \\
\text { aside from arrogance on the } \\
\text { part of the finger pointer. The } \\
\text { finger is thought to represent a } \\
\text { gun, or pointed weapon. } \\
\text { Strongly associated with anger, } \\
\text { directed at another person. }\end{array}$ \\
\hline 3. & hand(s) on & $\begin{array}{l}\text { confidence, } \\
\text { readiness, } \\
\text { availability }\end{array}$ & $\begin{array}{l}\text { The person is emphasizing } \\
\text { her/his presence and readiness } \\
\text { for action. Observable in } \\
\text { various situations, notably } \\
\text { sport, and less pronounced } \\
\text { poses in social and work } \\
\text { situations. In social and flirting } \\
\text { context it is said that the hands }\end{array}$ \\
\hline
\end{tabular}


LINGUA, Vol. 16, No. 2, September 2019

p ISSN: 1979 9411; e ISSN: 2442 238X

Http://lingua.soloclcs.org; Email: presslingua@gmail.com

Center of Language and Cultural Studies, Surakarta, Indonesia

Suhirman, Lalu. 2019. Body Language and Its Meaning:

the Interpretation of Body Language in the Little Black Book Film.

Lingua (2019), 16(2): 175-194. Http://doi.org/10.30957/lingua.v16i2.266.

\begin{tabular}{|l|l|l|l|}
\hline & & $\begin{array}{l}\text { are drawing attention to the } \\
\text { genital area. }\end{array}$ \\
\hline & & & \\
\hline
\end{tabular}

4.5. Other body languages

\begin{tabular}{|c|c|c|c|}
\hline $\mathrm{NO}$ & $\begin{array}{l}\text { The sign of Body } \\
\text { Language }\end{array}$ & $\begin{array}{l}\text { Possible } \\
\text { Meanining }\end{array}$ & Detailed Explanation \\
\hline 1 & $\begin{array}{l}\text { Walking while looking } \\
\text { forward }\end{array}$ & Searching future & $\begin{array}{l}\text { When people walking looking } \\
\text { forward, indicates that they } \\
\text { search future fate. As though } \\
\text { Stacy, She walked slowly } \\
\text { getting out from studio and } \\
\text { lookign forward for her future } \\
\text { living. }\end{array}$ \\
\hline 2 & Stacy and Barb & $\begin{array}{l}\text { Intimate, } \\
\text { encourage }\end{array}$ & $\begin{array}{l}\text { When people hold each other it } \\
\text { inicates to encourage someone } \\
\text { or show they are closed each } \\
\text { other }\end{array}$ \\
\hline 3 & $\begin{array}{l}\text { Breathing } \\
\text { (Clark convinces Stacy to } \\
\text { return back to on going life } \\
\text { program) }\end{array}$ & $\begin{array}{l}\text { Getting problem or } \\
\text { feeling free from } \\
\text { big problem }\end{array}$ & $\begin{array}{l}\text { Similarly breathing and } \\
\text { heartbeat, etc., are typically } \\
\text { excluded from many general } \\
\text { descriptions of body language, } \\
\text { but are certainly part of the } \\
\text { range of non-verbal bodily } \\
\text { actions and signals which } \\
\text { contribute to body language in } \\
\text { its fullest sense. }\end{array}$ \\
\hline 4. & Right hand raising, open & Asking permition, & Asking permition to do \\
\hline
\end{tabular}


LINGUA, Vol. 16, No. 2, September 2019

p ISSN: 1979 9411; e ISSN: 2442 238X

Http://lingua.soloclcs.org; Email: presslingua@gmail.com

Center of Language and Cultural Studies, Surakarta, Indonesia

Suhirman, Lalu. 2019. Body Language and Its Meaning:

the Interpretation of Body Language in the Little Black Book Film.

Lingua (2019), 16(2): 175-194. Http://doi.org/10.30957/lingua.v16i2.266.

\begin{tabular}{|l|l|l|}
\hline palm face to front & $\begin{array}{l}\text { want to state } \\
\text { important ideas. }\end{array}$ & $\begin{array}{l}\text { something or want to express } \\
\text { ideas, or want to ask Questions }\end{array}$ \\
& & \\
\hline
\end{tabular}

\section{DISCUSSION}

Nonverbal communication is a multichanneled process that is usuaUy performed sponta- neously; it typically involves a subtle set of nonlinguistic behaviors that are often enacted subconsciously'! Nonverbal behaviors can become part of the communication process when someone intentionally tries to convey a message or when someone attributes meaning to the nonverbal behavior of another, whether or not the person intended to communicate a particular mea ning, (Koester, 2010:198). Further Koester declares the characteristic of nonverbal communication. Nonverbal communication messages function as a "silent language" and impart their meanings in subtle and covert ways. People process nonverbal messages, both the send- ing and receiving of them, with less awareness than they process verbal messages. Contributing to the silent character of nonverbal messages is the fact that most of them are continuous and natural, and they tend to blur into one another. For example, raising one's hand to wave goodbye is a gesture made up of multiple muscular movements, yet it is interpreted as one continuous movement.

In this part it will be discussed body languages which has been identified in the "little Black Book" film. There are five main part of bady languages will be alaborated, (1) head, (2) eyes, (3) mouth, (4) hand, and (5) other body languages.

To interprete the meaning of each aspect of the body language will be analysed based on the multiple cultural petterns of society.

\subsection{Context of culture}

Body language also depends on the context of culture, means that different culture has different way to express happiness, likeness, sorrowness and possibly unaccepted on the other cultures. Body language in a certain situation might not mean th same in another. In many cultures, touching is reserved for those you know well- family, friends, neighbors, your favorite waiter or waitress, etc. Seldom will a person make physical contact with someone who is a total stranger. For example, when people are in an elevator they keep their distance from each other so as not to touch. And, if they're so crowded that their bodies come in contact, you have a group of very uptight people (Calero, 2005:12). 
LINGUA, Vol. 16, No. 2, September 2019

p ISSN: 1979 9411; e ISSN: 2442 238X

Http://lingua.soloclcs.org; Email: presslingua@gmail.com

Center of Language and Cultural Studies, Surakarta, Indonesia

Suhirman, Lalu. 2019. Body Language and Its Meaning:

the Interpretation of Body Language in the Little Black Book Film.

Lingua (2019), 16(2): 175-194. Http://doi.org/10.30957/lingua.v16i2.266.

Generally in Western societies and most other cultures, eye contact with a person is expected to be regular but not overly persistent, as constant eye contact is often considered to be an attempt at intimidation, causing the person who's the object of a person's gaze to feel overly studied and uncomfortable. Even between humans and nonhumans, persistent eye contact is sometimes unadvisable: the New Zealand Medical Journal reported that one reason so many young children fall victim to attacks by pet dogs is their over-poweringly regular eye contact with pets, which causes them to feel threatened and defensive (http://changingminds.org./techniques/htm.accessed, 20/07/2013).

Koester (2010:201) shows the roles of cultural context in nonverbal communication that all cultures have display rules that govern when and under what circumstances various nonverbal expressions are required, preferred, permitted, or prohibited. Thus, children learn both how to communicate nonverbally and the appropriate display rules that govern their nonverbal expressions. Display rules indicate such things as how far apart people should stand while talking, whom to touch and where, the speed and timing of movements and gestures, when to look directly at others in a conversation and when to look away, whether loud talking and expansive gestures or quietness and controlled movements should be used, when to smile and when to frown, and the overall pacing of communication.

\subsection{Body Language Related Age and Gender}

Many body language signals are relative.A gesture by one person in a certain situation can carry far more, or ver little meaning, compared to the same gesture used by a different person in a different situation.

Young men for example often display a lot of pronounced gestures because they are naturally eneretic, uninhibited and supple. Older women, relatively, are less energetic, adopt more modest postures, and are prevented by clothing and upbringing from exhibiting very pronounced gestures. So when assessing body language -espeially the strength of signals and meanings -it's important to do so in relative terms, considering the type of person and situation involved.

Women tend to have better perception and interpretation of body language than men, (http:/www.businessballs.com, cited 20/07/2013). Further stated that this is perhaps a feature of evolutionary survival, since female needed good body language skills to reduce their physical vulnerability tomales and the cosequential threat to life, limb and offspring. Females might not be so physically vulnerable in modern times, but their body language capabilities generally continue typically to be stronger than the male of the species. Thus, women tend to be able to employ body language (for sending and interpreting signals) more effectively than men.

Calero (2005:213) on the other sides denotes that in another area of cultural nonverbal communication is how men of various countries respond when they see a beautiful woman and signal their appreciation of female beauty. An American may lift his eyebrows and give a slow appreciative whistle or just exhale dramatically. An Italian male may press his right index finger to his cheek and then rotate it with an appreciative 
LINGUA, Vol. 16, No. 2, September 2019

p ISSN: 1979 9411; e ISSN: 2442 238X

Http://lingua.soloclcs.org; Email: presslingua@gmail.com

Center of Language and Cultural Studies, Surakarta, Indonesia

Suhirman, Lalu. 2019. Body Language and Its Meaning:

the Interpretation of Body Language in the Little Black Book Film.

Lingua (2019), 16(2): 175-194. Http://doi.org/10.30957/lingua.v16i2.266.

look on his face (Ekman, 2005; Wiley \& Sons, 2007). The drug which causes the pupils of the eye to dilate is named belladonna, which in Italian means "beautiful woman."

Adler and Rodman (Pantic, et al., 2007) indicated the result of a research about the distinction of women's and men's styles in (non-verbal) communication the notion that men and women communicate in dramatically different ways is exaggerated.Both men and women, at least in the dominant cultures of the United States and Canada,use language to build and maintain social relationships.Wiley \& Sons (2007) state that regardless of the sex of the communicators, the goals of almost all ordinary conversations include making the conversation enjoyable by being friendly,showing interest in what the other person says, and talking about topics that interest the other person. How men and women accomplish these goals is often different, though. Although most communicators try to make their interaction enjoyable,men are more likely than women to emphasize making conversation fun. Their discussions involve a greater amount of joking and good-natured teasing. By contrast,women's conversations focus more frequently on feelings, relationships, and personal problems, Adler and Rodman, 2005:99).

\subsection{Universal Communication Culture of Body Language}

Charles Darwin (in Nerenberg \& Calero, 2012) believed that certain nonverbal displays were universal. The shoulder shrug, for example, is used to convey such messages as "I can't do it," "I can't stop it from happening:' "It wasn't my fault, "Be patient:' and "I do not intend to resist:' Michael Argyle (in Lastig \& Koester, 2010) has listed a number of characteristics of nonverbal communication that are universal across all cultures: ( 1) the same body parts are called for nonverbal expressions; (2) nonverbal channels are used to convey similar information, emotions, values, norms, and selfdisclosing messages; (3) nonverbal messages accompany verbal communication and are used in art and ritual; (4) the motives for using the nonverbal channel, such as when speech is impossible, are similar across cultures; and (5) nonverbal messages are used to coordinate and control a range of contexts and relationships that are similar across cultures.

Koester stated (2010:201) about Paul Ekman's research on facial expressions demonstrates the universality of many nonverbal emotional displays? Ekman discovered three separate sets of facial muscles that operate independently and can be manipulated to form a variety of emotional ex pressions. These muscle sets include the forehead and brow; the eyes, eyelids, and base of the nose; and the cheeks, mouth, chin, and rest of the nose (Allan \& Pease, 2004 Crystal, 2008). The muscles in each of these facial regions are combined in a variety of unique patterns to display emotional states (James, 2007; Wiley \& Sons, 2007). For example, fear is indicated by a furrowed brow, raised eyebrows, wide-open eyes, creased or pinched base of the nose, taut cheeks, partially open mouth, and upturned upper lip (Bowden, 2010; Eggert, 2010). Because the ability to produce such emotional displays is consis- tent across cultures, there is probably a biological or genetic basis that allows these behaviors to be produced in all humans in a particular way. 
LINGUA, Vol. 16, No. 2, September 2019

p ISSN: 1979 9411; e ISSN: 2442 238X

Http://lingua.soloclcs.org; Email: presslingua@gmail.com

Center of Language and Cultural Studies, Surakarta, Indonesia

Suhirman, Lalu. 2019. Body Language and Its Meaning:

the Interpretation of Body Language in the Little Black Book Film.

Lingua (2019), 16(2): 175-194. Http://doi.org/10.30957/lingua.v16i2.266.

The universal cultural means of nonverbal communication we know of as "sign language" is taught to the deaf-mute by spelling words through the use of letter signs (De Gelder, 2006; Ekman, 2005; Lastig \& Koester, 2010). But what is less known is the shorthand gestures that communicate entire words, a phrase or even an entire sentence. This language is rarely committed to textbooks or taught in schools because instructors for the deaf frown on it (Crystal, 2008; Eggert, 2010; Neirenberg \& Calero, 2012). They prefer the practice of reading lips. Instead, deaf people learn the shorthand informallyfrom one deaf person to another. Another area of cultural nonverbal communication is how men of various countries respond when they see a beautiful woman and signal their appreciation of female beauty (Eggert, 2010; Neirenberg \& Calero). An American may lift his eyebrows and give a slow appreciative whistle or just exhale dramatically. An Italian male may press his right index finger to his cheek and then rotate it with an appreciative look on his face. The drug which causes the pupils of the eye to dilate is named belladonna, which in Italian means "beautiful woman." (Calero 2005; Bowden; 2010; Wiley \& Sons, 2007).

\section{CONCLUSION}

Body language is especially crucial when we meet someone for the firts time. We form our opinions of someone we meet for the first time in just a few seconds, and this initial instictual assessment is based on far more on what we see and feel about the other person than on the words they speak. On many occasions we form a strong view about a new person before they speak a single word. Consequently body language is very influential in forming impressions on first meeting someone. Body language is constantly being exchanged and interpreted between people, even though much of the time this is happening on an unconcious level.

Body language is also referred to as 'non-verbal communications', and less commonly 'non-vocal communications'. The term 'non-verbal communications' tends to be used in a wider sense, and all these terms are somewhat vague. Sometimes body language can have multiple meanings and are sometimes misinterpreted by people. When translating body language signals into feelings and meanings remember that one signal does not reliably indicate a meaning. Body language should not be used alone for making serious decisions about people. Body language is one of several indicators of mood, meaning and motive.

\section{RFERENCES}

Adler, Ronald, B., \& Rodman, George. 2000. Understanding Human Communication. (9th. Ed.). Oxford University Press.

Allan \& Pease, B. (2004). The Definitive Book of Body Language: How Body Language Reveals Emotions and Thoughts. Australia: McPherson's Printing Group

Albert, M. (1971). Silent Messages. (1st edition). Belmont, CA: Wadsworth. 
LINGUA, Vol. 16, No. 2, September 2019

p ISSN: 1979 9411; e ISSN: 2442 238X

Http://lingua.soloclcs.org; Email: presslingua@gmail.com

Center of Language and Cultural Studies, Surakarta, Indonesia

Suhirman, Lalu. 2019. Body Language and Its Meaning:

the Interpretation of Body Language in the Little Black Book Film.

Lingua (2019), 16(2): 175-194. Http://doi.org/10.30957/lingua.v16i2.266.

Bowden, M. (2010). Winning Body Language; Control the Conversation, Command Attention, and Convey the Right Message - Without Saying a Word. New York: McGraw-Hill.

Calero, Henry,H. 2005. The Power of Nonverbal Communication. Los Angeles: Silver Lake Publisher.

Crystal, D. (2003).The Cambridge Encyclopaedia of the English Language. Cambridge:Cambridge University Press.

De Gelder, B. (2006). Towards the neurobiology of emotional body language. Nat RevNeurosci. VOL. 7(3): (242-249).

Eggert, M.A. (2010). Body Language: Impress, Persuade and succeed with the power of body language. New York: Prentice Hall.

Ekman, P. (2005). What the face reveals (2nd edition): Basic and applied studies of spontaneous expression using the Facial Action Coding System (FACS). (p. $388-$ 392).

James, J. (2007). The Body Language Rules: A Savvy Guide to Understanding Who's Flirting, Who's Faking, and Who's Really Interested. Nappille, Illinois: Sourcebooks, Inc.

Knapp, M. (1978). Nonverbal Communication in Human Interaction. (2nd Edition) Holt, Rinehart and Winston Inc., New York.

Lastig, M.,W., \& Koester,J.(2010). Intercultural Competence: Interpersonal Communication accross Cultures. (6th Ed.). Unitate States: Pearson Education, Inc.

Neirenberg, G.I. \&Calero, H.H. (2012). How to Read a Person Like a Book. New York: Simons \& Schuster Inc.

Pantic, M. A. Pentland, A. Nijholt, A. and Huang, T. (2007). Human computing and machine understanding of human behavior: A survey. In T.S. Huang, A. Nijholt, M. Pantic, and A. Pentland, editors, Artificial Intelligence for Human Computing, volume 4451, (pages 47-71), Springer.

Wiley. J. \& Sons. (2007). Body Language For Dummies. England: John Wiley \& Sons, Ltd The Atrium Southern Gate Chichester West Sussex PO19 8SQ

http://www.businessballs.com/search businessballs.htm? $\mathrm{cx}=010837026464449256333)$. 
LINGUA, Vol. 16, No. 2, September 2019

p ISSN: 1979 9411; e ISSN: 2442 238X

Http://lingua.soloclcs.org; Email: presslingua@gmail.com

Center of Language and Cultural Studies, Surakarta, Indonesia

Suhirman, Lalu. 2019. Body Language and Its Meaning:

the Interpretation of Body Language in the Little Black Book Film.

Lingua (2019), 16(2): 175-194. Http://doi.org/10.30957/lingua.v16i2.266.

\section{Appendix}

\section{THE SYNOPSIS OF THE FILM}

\begin{tabular}{|c|c|}
\hline & $\begin{array}{l}\text { BODY LANGAGE ANALYSIS } \\
\text { (Little Black Book - a Romantic Film }\end{array}$ \\
\hline \multicolumn{2}{|l|}{ REVIEW } \\
\hline Title & : Little Black Book \\
\hline Directed by & : Nick Hurran \\
\hline \multirow[t]{4}{*}{ Produced by } & : Elaine Goldsmith \\
\hline & : Deborah Schindler \\
\hline & : William Sherak \\
\hline & : Johnson Shuman \\
\hline Executive Production & : Herbert W. Gains and Rachael Horovitz \\
\hline Story by & : Mellisa Carter \\
\hline Production Designer & : Bob Ziembiki \\
\hline Editor by & : John Richard \\
\hline Screenplay by & : Mellisa Carter \& Elisa Bell \\
\hline Casting by & : Nancy Nayor Battino, CSA \\
\hline \multirow[t]{9}{*}{ Starring } & : Stacy (Brittany Murphy) \\
\hline & Barbs (Holly Hunter) \\
\hline & Keppi Kann (Kathy Bates) \\
\hline & Derek (Ron Livingston) \\
\hline & Carl (Stephene Tobolosky \\
\hline & Ira (Kevin Sussman) \\
\hline & Dr. Rachel Keys: Roshida Jones \\
\hline & Joyce(Julianne Nicholson) \\
\hline & Lulu Fritz (Josie Maran) \\
\hline Music by & : Christophe Beck \\
\hline Costum Designer & : Susie Desanto \\
\hline \multirow[t]{2}{*}{ Studio } & : Revolution \\
\hline & Colombia Pictures \\
\hline Release date(s) & : August 3rd, 2004, Collombia - America \\
\hline
\end{tabular}

The Little Black Book film telling about a young pretty girl, Stacy Holt found a job as a TV tabloid program after finishing her study at the University. That was her ambition since she was a child. Accidently, Stacy met Derek a young handsome boy, a hocky player in a bar. In her first day at the TV Tabloid, she was introduced to Barb by Ira Naclace a staff of Keppi Kann life program. Barb was an assisstent of Keppi Kann Program at the TV Tabloid. Then, Ira and Barb took her to a sample live show being presented by Keppi Kann about a spouse who was not match each other. It seemed that Stacy really interested in this program.

Stacy lived together with Derek since her introduction with Derek at the bar. They loved each other. In one day, Derek and Stacy watching TV, unfortunately Lulu Fritz a famous model appeared on the TV screen that made Derek threw impolite words to Lulu. Stacy looked suprise with Derek words to Lulu. Stacy asked who Lulu was to Derek. Derek replied Stacy's question, "she was my past time, and she was a vomit". Stacy was surprised that Derek knew how Lulu vomit. Stacy felt jelous and tried to ask many things about Lulu, but Derek didn't want to reply truthfully. 
LINGUA, Vol. 16, No. 2, September 2019

p ISSN: 1979 9411; e ISSN: 2442 238X

Http://lingua.soloclcs.org; Email: presslingua@gmail.com

Center of Language and Cultural Studies, Surakarta, Indonesia

Suhirman, Lalu. 2019. Body Language and Its Meaning:

the Interpretation of Body Language in the Little Black Book Film.

Lingua (2019), 16(2): 175-194. Http://doi.org/10.30957/lingua.v16i2.266.

When Derek left home for hocky, Stacy then looked for some documents in a Derek's box. She found two women's photos, dr. Rachel Keys and Joyce. Stacy became distrusful to Derek. She thought that he loved only herself. On the other day, when Stacy was at the office, she told Ira and Barb about Derek's past time and his former girl friends. Both Ira and Barb felt responsibility to their friend's heart feeling (Stacy's heart), then they made a trick. They used TV facility to interview Lulu for far distance. While for Rachel and Joyce, Barb asked Stacy to prove directly by pretending a wart patient at Rachel's clinic, and as a journalist of Keppi Kann for Joyce.

Ira and Barb had arranged Stacy's meeting with Rachel and Joyce. Stacy easily met dr. Rachel at her clinic. Tracy saw a fohto on the wall, those were dr. Rachel and Derek's dog. In one occation, Tracy met Joyce in a coffee. Joyce proudly told her experience with Derek. She also told to Stacy that she almost got marry with Derek. Joyce decided to sparate with Derek because of the existance of Lulu Fritz. "Lulu tried to tease Derek", said Joyce. Joyce suddently felt confortable with Stacy and then invited Stacy to accompany her to watch hocky championship.

Stacy went to her office at TV Tabloid with a distressed feeling because she had made Joyce was sad with her last time. She walked slowly and lazily to Barb and said, "I'm not well and I wana go home". But Barb avoided and held her, because they had an important life show TV on Keppi Kann programe to infoam. It wasn't long, Ira came to them that Keppi Kann life show program immeditely would be started. Keppi was in the studio show. Stacy and Barb ran fasly to studio. When they arrived at the studio show, Barb pushed Stacy to go in to the studio. All audiences clapped hands and stood up, while Keppi wellcame to Stacy who looked confuse. To netralize the situation and normalized Stacy's emotion, Keppi asked to Stacy, "Stacy wahat is our program now?". "night mare of plastic sergion", Stacy replied. "No", said Keppi and continued, "Little Black Book".

Suddently, Keppi kann invited Lulu Fritz, dr. Rachel, and Joyce. Not so long, Keppi also invited Derek to come in as the information clue in this program. Stacy was very unconfortable and embarrassing on that time. She never assumed that event happened. All guesses or interviewees protested and got angry. Stacy herself protested to Clark as the program leader. But Clark just asked Stacy to continue the program bacause it would finish soon, and asked everyone to protest. At last, Stacy went in and requested to Keppi for asking Derek. Stacy forced Derek to addmit his former girl friends those all were in the studio. Stacy dicided to seperate with Derek and suggested him retun back to his genuine love with Joyce.

Stacyhad made her mother proud of her, because she had helped her mother to earn the living as a single parent. Stacy gave up her work at the TV tabloid program because of the life show KeppiKann TV program where Stacy herself as the source of the program. The program was "Little Black Book" which bridged a meeting of all former girl friends of her boy friend on KeppiKann program. That program conducted based on Stacy's investigation about her boy friend'sgirl friends. This program conducted accidently without being known by Stacy. Conversely, Stacy felt uncomfortable with her former girl friends, Rachel a doctor of a pregnant clinic, Lulu Fritz as a model, and Joyce as a chef at a coffee. Finally she gave up from TV tabloid, and found new job as a magazine staff. 
LINGUA, Vol. 16, No. 2, September 2019

p ISSN: 1979 9411; e ISSN: 2442 238X

Http://lingua.soloclcs.org; Email: presslingua@gmail.com

Center of Language and Cultural Studies, Surakarta, Indonesia

Suhirman, Lalu. 2019. Body Language and Its Meaning:

the Interpretation of Body Language in the Little Black Book Film.

Lingua (2019), 16(2): 175-194. Http://doi.org/10.30957/lingua.v16i2.266.

\section{BODY LANGUAGE AND ITS MEANING \\ (The Interpretation of Body Lanuage in LittleBlack Book Film)}
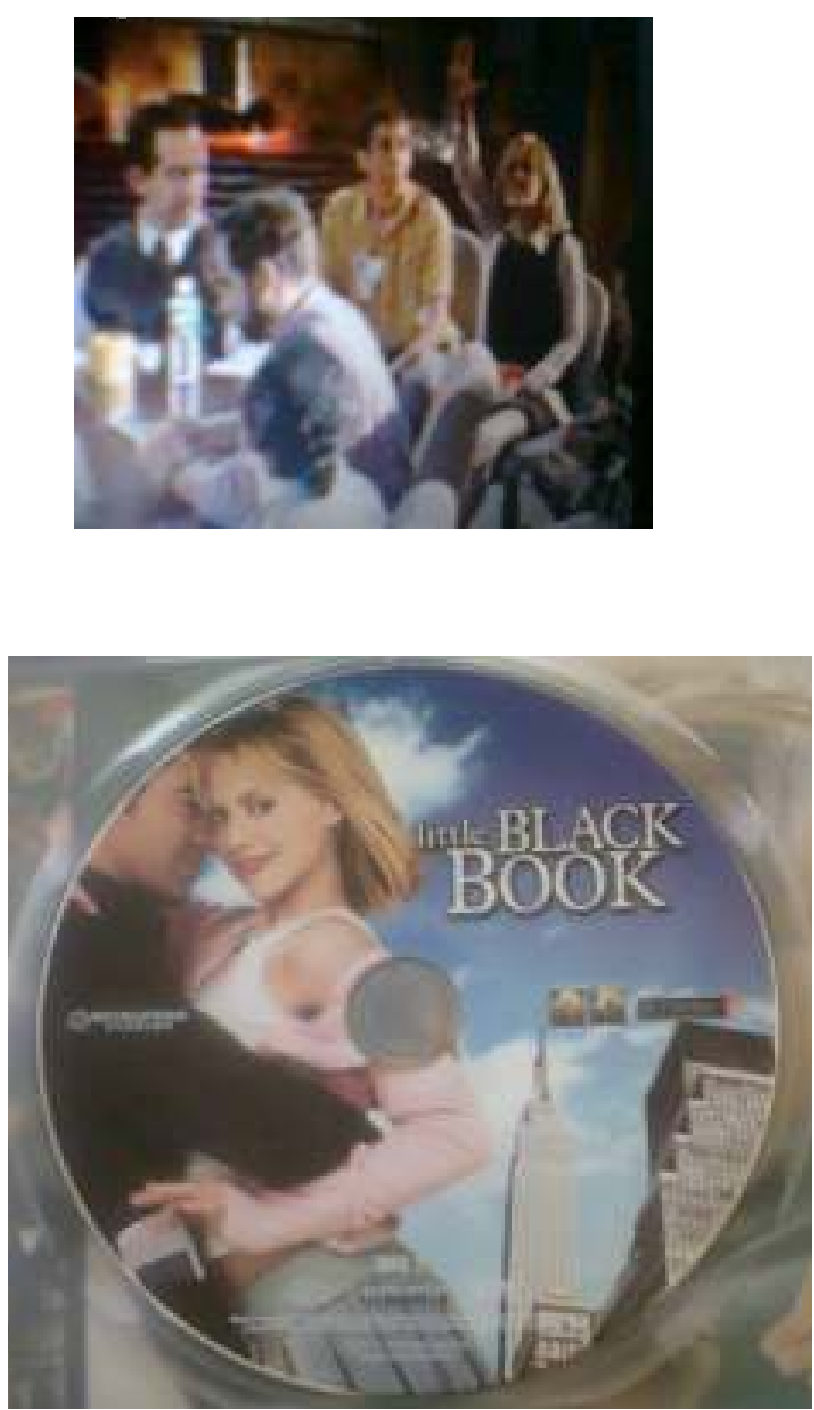
LINGUA, Vol. 16, No. 2, September 2019

p ISSN: 1979 9411; e ISSN: 2442 238X

Http://lingua.soloclcs.org; Email: presslingua@gmail.com Center of Language and Cultural Studies, Surakarta, Indonesia

Suhirman, Lalu. 2019. Body Language and Its Meaning: the Interpretation of Body Language in the Little Black Book Film.

Lingua (2019), 16(2): 175-194. Http://doi.org/10.30957/lingua.v16i2.266. 